\title{
Stability Constants of Mixed Ligand Complexes of Nickel(II) with Adenine and Some Amino Acids
}

\author{
Naciye Türkel \\ Faculty of Arts and Sciences, Department of Chemistry, Uludağ University, 16059 Bursa, Turkey \\ Correspondence should be addressed to Naciye Türkel; nturkel@uludag.edu.tr
}

Received 2 November 2015; Revised 5 December 2015; Accepted 7 December 2015

Academic Editor: Giovanni Natile

Copyright (C) 2015 Naciye Türkel. This is an open access article distributed under the Creative Commons Attribution License, which permits unrestricted use, distribution, and reproduction in any medium, provided the original work is properly cited.

\begin{abstract}
Nickel is one of the essential trace elements found in biological systems. It is mostly found in nickel-based enzymes as an essential cofactor. It forms coordination complexes with amino acids within enzymes. Nickel is also present in nucleic acids, though its function in DNA or RNA is still not clearly understood. In this study, complex formation tendencies of Ni(II) with adenine and certain L-amino acids such as aspartic acid, glutamic acid, asparagine, leucine, phenylalanine, and tryptophan were investigated in an aqueous medium. Potentiometric equilibrium measurements showed that both binary and ternary complexes of Ni(II) form with adenine and the above-mentioned $\mathrm{L}$-amino acids. Ternary complexes of $\mathrm{Ni}$ (II)-adenine-L-amino acids are formed by stepwise mechanisms. Relative stabilities of the ternary complexes are compared with those of the corresponding binary complexes in terms of $\Delta \log _{10} K, \log _{10} X$, and \% RS values. It was shown that the most stable ternary complex is $\mathrm{Ni}(\mathrm{II})$ :Ade:L-Asn while the weakest one is $\mathrm{Ni}(\mathrm{II})$ :Ade:L-Phe in aqueous solution used in this research. In addition, results of this research clearly show that various binary and ternary type $\mathrm{Ni}(\mathrm{II})$ complexes are formed in different concentrations as a function of $\mathrm{pH}$ in aqueous solution.
\end{abstract}

\section{Introduction}

Metal ions form different complexes with various biological macromolecules or with their synthetic derivatives [1]. Nickel is one of the trace elements found in certain enzymes as cofactor [2]. Interestingly, seven out of the eight nickel-based enzymes produce or use gases in their reactions. These gases are $\mathrm{CO}, \mathrm{CO}_{2}, \mathrm{CH}_{4}, \mathrm{H}_{2}$, and $\mathrm{NH}_{3}$ [2]. Efficacy and the specificity of nickel-based enzymes depend upon the exact coordination of nickel atom within the active site of the enzyme [3]. Both the coordination and the stability of nickel atom within the active sites of Ni-based enzymes are affected by the amino acid residues and their side chains within the active sites of those enzymes. For example, in the nickel-based superoxide dismutase (Ni-SOD) enzyme, single nickel atom is coordinated via sulfur side chains of two cysteines together with the two atoms of nitrogen from peptide backbone [4].

Metal ions also affect the structure of DNA and RNA within the cell. Metal ions, such as $\mathrm{Mg}^{2+}, \mathrm{Ca}^{2+}, \mathrm{Mn}^{2+}, \mathrm{Cu}^{2+}$, $\mathrm{Zn}^{2+}, \mathrm{Cd}^{2+}$, and $\mathrm{Pb}^{2+}$, can bind and distort the structure of double stranded DNA and even can form triplex or tetraplex DNA structures [5]. For example, it is a well known fact that the $\mathrm{K}^{+}$ions form tetraplex DNA when they bind to Guanine rich region of chromatins $[5,6]$. These types of abnormal structures on DNA may cause detrimental effects such as triplet expansion diseases [7]. It has been shown that the Schiff base complexes of $\mathrm{Ni}(\mathrm{II}), \mathrm{Cu}(\mathrm{II})$, and $\mathrm{Zn}(\mathrm{II})$ can bind to DNA with very high affinity in aqueous solutions $[8,9]$. Schiff base complexes of these metal ions can be used as antimicrobial complexes since they can inhibit the growth of pathogenic bacteria $[8,9]$. Moreover, coordination complexes of certain metal ions, including $\mathrm{Ni}$ (II) complexes, have a great potential to be "catalytic metallodrugs" for selective activation or degradation of target biological molecules like viral RNAs [10].

Most of the studies on the stability and the coordination of nickel in enzymes or in nucleic acids has been done using whole enzymes and large nucleic acid molecules $[4,5,11]$. However, stability and the coordination of nickel within the metal centers of the enzymes are influenced by the tridimensional structure and also by the substrate binding sites of these type enzymes. In addition, nickel can be found with other metal ions, such as iron, in certain Ni-based enzymes [2]. Furthermore, super coiled structures of nucleic acids may 
also interfere with stable interactions of $\mathrm{Ni}(\mathrm{II})$ with individual bases of DNA or RNA [5].

In a past study, Krause et al. examined the interaction and the stability of $\mathrm{Ni}(\mathrm{II})$ with amino acids with dipeptide which is composed of asparagine-cysteine-cysteine (also known as NCC peptide) instead of whole enzyme nickel superoxide dismutase (Ni-SOD) [12]. In that study, it has been shown that coordination of $\mathrm{Ni}(\mathrm{II})$ within the active site of $\mathrm{Ni}$-SOD can be mimicked by NCC tripeptide. Biological systems have a large set of target molecules for metal ion interactions. In addition to nickel, metal ions such as sodium, potassium, magnesium, calcium, manganese, iron, cobalt, copper, zinc, and molybdenum are also present within different types of living cells and they compete with each other to form various metal-ligand complexes with biological macromolecules $[1,13]$. In certain cases, metal ions should form relatively weak interactions with proteins as in the cases of metal ion transporters [14]. On the contrary, metal ions interact rather strongly with the amino acids in the active sites of metalloenzymes [14]. Hence, it is important to analyze the strength of the metal-ligand interactions in aqueous solution with mixed ligand systems.

In this study, stabilities of the binary and ternary complexes of nickel with adenine and free amino acids L-Asp, L-Glu, L-Asn, L-Leu, L-Phe, and L-Trp were investigated in aqueous solution by potentiometric methods. Results of this study indicate that stabilities of binary and ternary complexes of $\mathrm{Ni}(\mathrm{II})$ with these ligands depend on the $\mathrm{pH}$ of the aqueous solution and the structure of the L-amino acids. Results of this research can be used to evaluate the interactions of nickel ions with DNA bases and L-amino acids in aqueous solution in the presence of mixed ligands at molecular level.

\section{Material and Methods}

2.1. Materials. Stock solution of the nickel $\left(\sim 0.01 \mathrm{~mol} \cdot \mathrm{L}^{-1}\right)$ used in the study was prepared from the nitrate salt of $\left(\mathrm{Ni}\left(\mathrm{NO}_{3}\right)_{2} \cdot 6 \mathrm{H}_{2} \mathrm{O}\right)$. This stock solution was acidified with $\mathrm{HCl}$ to prevent the hydrolysis of the metal, and concentration of the acid solution was determined through Gran method potentiometrically [15]. Concentration of the $\mathrm{Ni}(\mathrm{II})$ solution was determined by complexometric EDTA titration [1517]. Potassium hydrogen phthalate was used to standardize carbonate-free sodium hydroxide (titrant, prepared in $0.1 \mathrm{~mol} \cdot \mathrm{L}^{-1} \mathrm{KNO}_{3}$ solution) potentiometrically $[18,19]$. The amino acids (L-Asp (98\%), L-Glu (99.5\%), L-Asn (98\%), LLeu (98\%), L-Phe (98\%), and L-Trp (98\%)) and adenine (99\%) were used as received. An $\mathrm{HCl}$ solution $\left(0.1 \mathrm{~mol} \cdot \mathrm{L}^{-1}\right)$ was prepared and used after standardization as described [20]. All of the solutions used during the experiments were prepared freshly in ultra pure water having a resistivity of $18.3 \mathrm{~mol} \cdot \mathrm{L}^{-1} \Omega \mathrm{cm}$. Samples of all of the aqueous solutions were prepared gravimetrically.

2.2. pH-Metric Measurements. A special glass vessel for potentiometric titrations device was used as explained in previous studies [21]. This titration system has a double wall, with entries for combined glass electrode (Schott), nitrogen, and base from the burette (TL 7000-M2/20 automatic titrator). The emf measurements were carried out with the cited automatic titrator every 4 minutes. Temperature inside the cell was kept constant at $(25.0 \pm 0.1)^{\circ} \mathrm{C}$, through circulation of water from an external thermostat (RW-0525G). Each of the investigated solutions was thermostated at the necessary temperature with an accuracy of $\pm 0.1^{\circ} \mathrm{C}$, and the solutions were left to stand at this temperature for $15 \mathrm{~min}$ prior to titration. Calibration of the combined glass electrode was performed in both acidic and alkaline regions by titrating $0.01 \mathrm{~mol} \mathrm{~L}^{-1}$ hydrochloric acid with standard sodium hydroxide prior to each titration to read the hydrogen ion concentration directly so that the $\mathrm{p}[\mathrm{H}]$ is defined as $-\log _{10}[\mathrm{H}][22]$. The emf values (E) depend on $\left[\mathrm{H}^{+}\right]$according to $E=E^{o}+s \log _{10}\left[\mathrm{H}^{+}\right]+$ $J_{\mathrm{H}}\left[\mathrm{H}^{+}\right]+J_{\mathrm{OH}}\left[\mathrm{OH}^{-}\right]$, where $J_{\mathrm{H}}$ and $J_{\mathrm{OH}}$ are fitting parameters in acidic and alkaline media in order to correct experimental errors. These errors arise mainly from the liquid junction and the alkaline and acidic errors of the glass electrode. The autoprotolysis constant of water, $\mathrm{p} K_{\mathrm{w}}$ for the aqueous system, defined as $-\log _{10}\left(\left[\mathrm{H}^{+}\right]+\left[\mathrm{OH}^{-}\right]\right)$at the ionic strength used, was found to be $\sim 13.85$.

Total volume in all potentiometric titrations was adjusted to $50 \mathrm{~mL}$. The following reaction mixtures (described from reactions (a) to (i)) containing proton and/or $\mathrm{Ni}(\mathrm{II})$ nitrate and the ligands at different ratios $(1: 1),(1: 2)$, and $(1: 3)$ in binary systems, and $(1: 1: 1)$ in ternary systems, were titrated through incremental additions of carbonate-free and standard $\mathrm{NaOH}$ :

(a) $\mathrm{HCl}\left(0.1 \mathrm{~mol} \cdot \mathrm{L}^{-1}, 5.0 \mathrm{~mL}\right)+\left(1.0 \mathrm{~mol} \cdot \mathrm{L}^{-1}, 5.0 \mathrm{~mL}\right.$ $\left.\mathrm{KNO}_{3}\right)+\mathrm{H}_{2} \mathrm{O}$ (for cell calibration).

(b) $\mathrm{HCl}\left(0.1 \mathrm{~mol} \cdot \mathrm{L}^{-1}, 2.0 \mathrm{~mL}\right)+\left(1.0 \mathrm{~mol} \cdot \mathrm{L}^{-1}, 5.0 \mathrm{~mL}\right.$ $\left.\mathrm{KNO}_{3}\right)+\mathrm{H}_{2} \mathrm{O}$.

(c) Solution (b) + Ade (A, $0.01 \mathrm{mmol}$ ) (for determining the protonation constants of Ade).

(d) Solution (b) + amino acids (B, $0.01 \mathrm{mmol}$ ) (for determining the protonation constants of amino acids).

(e) Solution (b) + Ade (A, $0.01 \mathrm{mmol})+\mathrm{Ni}$ (II) $\left(0.01 \mathrm{~mol} \cdot \mathrm{L}^{-1}, 10.0 \mathrm{~mL}\right.$ ) (for determining the stability constants of the NiA binary complexes).

(f) Solution (b) + Ade (A, $0.02 \mathrm{mmol})+\mathrm{Ni}(\mathrm{II})$ $\left(0.01 \mathrm{~mol} \cdot \mathrm{L}^{-1} 10.0 \mathrm{~mL}\right.$ ) (for determining the stability constants of the $\mathrm{NiA}_{2}$ binary complexes).

(g) Solution (b) + amino acids (B, $0.01 \mathrm{mmol})+\mathrm{Ni}(\mathrm{II})$ $\left(0.01 \mathrm{~mol} \cdot \mathrm{L}^{-1}, 10.0 \mathrm{~mL}\right)$ (for determining the stability constants of the $\mathrm{NiB}$ binary complexes).

(h) Solution (b) + amino acids (B, $0.02 \mathrm{mmol})+\mathrm{Ni}(\mathrm{II})$ $\left(0.01 \mathrm{~mol} \cdot \mathrm{L}^{-1}, 10.0 \mathrm{~mL}\right.$ ) (for determining the stability constants of the $\mathrm{NiB}_{2}$ binary complexes).

(i) Solution (b) + Ade (A, $0.01 \mathrm{mmol})+$ amino acids (B, $0.01 \mathrm{mmol})+\mathrm{Ni}(\mathrm{II})\left(0.01 \mathrm{~mol} \cdot \mathrm{L}^{-1}, 10.0 \mathrm{~mL}\right)$ (for determining the stability constants of the NiAB $(1: 1: 1)$ ternary complexes).

Titrations for each set were conducted at least four times in order to check the reproducibility of the data. These systems were evaluated in the $\mathrm{pH}$ range of $1.5-10.5$, since the changes in ionic strength and the $\mathrm{p}[\mathrm{H}]$-dependence of the junction potentials could affect the accuracy. 
<smiles>Nc1ncnc2[nH]cnc12</smiles><smiles>CC(C)C[C@H](N)C(=O)O</smiles>

L-Leucine<smiles>NC(CC(=O)O)C(=O)O</smiles><smiles>NC(CCC(=O)O)C(=O)O</smiles>

L-Glutamic acid<smiles>N[C@@H](Cc1ccccc1)C(=O)O</smiles>

L-Phenylalanine<smiles>NC(=O)C[C@H](N)C(=O)O</smiles>

L-Asparagine<smiles>N[C@@H](Cc1c[nH]c2ccccc12)C(=O)O</smiles>

L-Tryptophan

Figure 1: Structures of the ligands in this study.

\section{Results and Discussion}

3.1. Proton-Ligand Equilibria. Nickel can interact with various amino acids and their side chains within the active sites of nickel-based enzymes [2]. To analyze the stabilities of nickel complexes with L-amino acids in aqueous solution, six different types of L-amino acids were selected based on the biochemical features of their side chains. These L-amino acids are L-Asp, L-Glu, which have negatively charged Rgroups, and L-Asn that has an uncharged polar R-group. LLeu, L-Phe, and L-Trp were selected as an example to apolar R-groups containing L-amino acids. Adenine was selected for sample base due to its significant role in the ATP and ADP in the biological reactions.

Protonation constants of adenine and amino acids ( $\mathrm{L}$ Asp, L-Glu, L-Asn, L-Leu, L-Phe, and L-Trp) (open formulae of the ligands selected for this study are provided in Figure 1) examined in this study were determined by potentiometric method using the computer program named "BEST" developed through Martell and Motekaitis at $0.1 \mathrm{~mol} \cdot \mathrm{L}^{-1} \mathrm{KNO}_{3}$ ionic medium and $25.0^{\circ} \mathrm{C}$ [23]. Protonation constants of all of the ligands determined in this study were listed in Table 1. It is clear that all protonation constants $\left(\log _{10} K_{1}, \log _{10} K_{2}\right.$, and $\log _{10} K_{3}$ ) of Ade and L-amino acids identified in this research are very close to previously reported values for those ligands (Table 1) [24-32].

3.2. Nickel(II)-Adenine Equilibria. Adenine was titrated alone and in the presence of $\mathrm{Ni}$ (II) ion potentiometrically. Potentiometric titration curve of the $\mathrm{Ni}$ (II):Ade system was given in Figure 2, curve II. The decrease in the $\mathrm{pH}$ value of the reaction mixture indicated that $\mathrm{Ni}(\mathrm{II})$ :Ade complexes form at $1: 1$ and $1: 2$ mol ratios as seen in Figure 2, curve II for $(1: 1)$ and curve III for $(1: 2)$ binary complexes of $\mathrm{Ni}(\mathrm{II})$ :Ade, respectively. Hamada et al. demonstrated in their work that large metal ions (such as $\mathrm{Cd}$ (II) or $\mathrm{Hg}$ (II) with ionic radius = 95 and $102 \mathrm{pm}$, resp.) will coordinate in a chelate fashion between
TABLE 1: The protonation constants of the ligands at $25.0 \pm 0.1^{\circ} \mathrm{C}, I$ $=0.1 \mathrm{~mol} \cdot \mathrm{L}^{-1} \mathrm{KNO}_{3}$.

\begin{tabular}{|c|c|c|c|}
\hline & $\log _{10} K_{1}$ & $\log _{10} K_{2}$ & $\log _{10} K_{3}$ \\
\hline \multirow{4}{*}{$\operatorname{Ade}(\mathrm{A})$} & $9.60 \pm 0.06$ & $4.18 \pm 0.07$ & \\
\hline & $9.60[24]$ & $3.90[24]$ & \\
\hline & $9.62[25]$ & $4.20[25]$ & \\
\hline & $9.92[26]$ & $4.19[26]$ & \\
\hline \multirow{4}{*}{ L-Asp(B) } & $9.61 \pm 0.03$ & $3.74 \pm 0.03$ & $2.00 \pm 0.03$ \\
\hline & 9.64 [25] & $3.70[25]$ & 1.98 [25] \\
\hline & 9.82 [27] & 3.86 [27] & 2.10 [27] \\
\hline & 9.48 [28] & $3.87[28]$ & $2.48[28]$ \\
\hline \multirow{4}{*}{ L-Glu(B) } & $9.57 \pm 0.05$ & $4.16 \pm 0.05$ & $2.19 \pm 0.05$ \\
\hline & 9.58 [25] & 4.14 [25] & $2.16[25]$ \\
\hline & $9.41[27]$ & 4.15 [27] & $2.65[27]$ \\
\hline & 9.98 [29] & 4.37 [29] & 2.05 [29] \\
\hline \multirow{3}{*}{ L-Asn(B) } & $8.78 \pm 0.02$ & $2.17 \pm 0.02$ & \\
\hline & 8.73 [25] & $2.16[25]$ & \\
\hline & $8.45[24]$ & $1.70[24]$ & \\
\hline \multirow{3}{*}{ L-Leu(B) } & $9.52 \pm 0.05$ & $2.31 \pm 0.05$ & \\
\hline & 9.56 [25] & 2.34 [25] & \\
\hline & $9.58[30]$ & $2.32[30]$ & \\
\hline \multirow{3}{*}{ L-Phe(B) } & $9.14 \pm 0.07$ & $2.19 \pm 0.07$ & \\
\hline & 9.10 [25] & $2.18[25]$ & \\
\hline & $9.75[31]$ & $2.14[31]$ & \\
\hline \multirow{3}{*}{ L-Trp (B) } & $9.38 \pm 0.03$ & $2.31 \pm 0.03$ & \\
\hline & $9.33[25]$ & $2.28[25]$ & \\
\hline & $9.14[32]$ & $2.22[32]$ & \\
\hline
\end{tabular}

Uncertainties are expressed as \pm one standard deviation.

the $\mathrm{N}(3)$ and $\mathrm{N}(9)$ in adenine. Smaller metal ions such as $\mathrm{Zn}$ (II) (74 pm) will fit in the smaller chelate ring between the $\mathrm{N}(7)$ and $\mathrm{N}(10)$ in adenine as shown in Figure 1 [33]. The stability constants of these complexes, which were formed, 
TABLE 2: The stability constants of binary complexes at $25.0 \pm 0.1^{\circ} \mathrm{C}$, $I=0.1 \mathrm{~mol} \cdot \mathrm{L}^{-1} \mathrm{KNO}_{3}$.

\begin{tabular}{lccc}
\hline & $\log _{10} \beta_{1}$ & $\log _{10} \beta_{2}$ & $\log _{10} \beta_{3}$ \\
\hline & $6.66 \pm 0.06$ & $12.22 \pm 0.06$ & \\
Ni(II):adenine(A) & $7.88[34]$ & & \\
& $6.66[35]$ & $11.11[35]$ & \\
& $8.14 \pm 0.06$ & $12.70 \pm 0.06$ & \\
Ni(II):L-Asp(B) & $7.14[36]$ & $12.43[36]$ & \\
& $7.25[37]$ & & \\
& $5.34 \pm 0.03$ & $10.36 \pm 0.03$ & $13.43 \pm 0.03$ \\
Ni(II):L-Glu(B) & $6.06[38]$ & $10.33[38]$ & $12.51[38]$ \\
& $8.02 \pm 0.05$ & $18.29 \pm 0.05$ & $25.55 \pm 0.04$ \\
Ni(II):L-Asn(B) & $8.64[39]$ & $17.26[39]$ & $25.64[39]$ \\
& $5.53 \pm 0.04$ & $11.78 \pm 0.04$ & \\
Ni(II):L-Leu(B) & $5.5575[40]$ & $9.1013[40]$ & \\
& $6.52 \pm 0.02$ & $10.10 \pm 0.02$ & $16.58 \pm 0.02$ \\
Ni(II):L-Phe(B) & $5.4034[40]$ & $9.4963[40]$ & \\
& $5.45 \pm 0.02$ & $9.64 \pm 0.02$ & $13.62 \pm 0.02$ \\
Ni(II):L-Tryp(B) & $5.76[41]$ & $10.98[41]$ & $15.46[41]$ \\
\hline
\end{tabular}

Uncertainties are expressed as \pm one standard deviation.

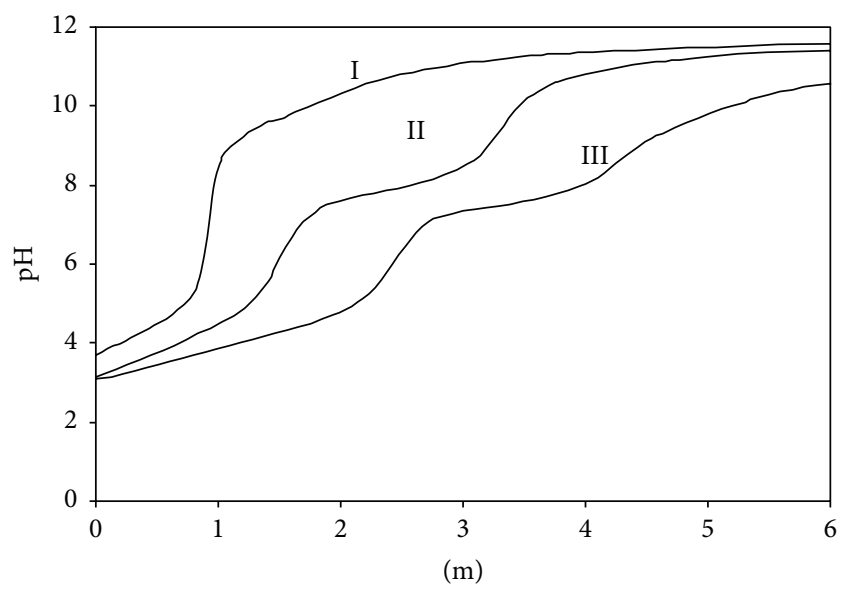

FIgURE 2: Potentiometric titration curves of binary complexes ( $I=$ $0.1 \mathrm{~mol} \cdot \mathrm{L}^{-1} \mathrm{KNO}_{3}$ at $\left.25.0 \pm 0.1^{\circ} \mathrm{C}\right)$. Curve I: adenine alone, curve II: $\mathrm{Ni}(\mathrm{II})$ :adenine $(1: 1)$, and curve III: $\mathrm{Ni}(\mathrm{II})$ :adenine $(1: 2)$.

were calculated (according to (1) and (2)) at $0.1 \mathrm{~mol} \cdot \mathrm{L}^{-1} \mathrm{KNO}_{3}$ ionic medium and $25.0^{\circ} \mathrm{C}$ temperature with BEST computer program and given in Table 2. From these results, it was seen that the results presented in the previous literature were coherent with the values of this research $[34,35]$.

In the following reactions and equations, $\mathrm{Ni}(\mathrm{II})$ metal ion and adenine (A:Ade) are present in $(1: 1)$ and $(1: 2)$ stoichiometry, respectively. The equilibrium reactions and equations (1) and (2) are given for binary complex systems which form in these situations.

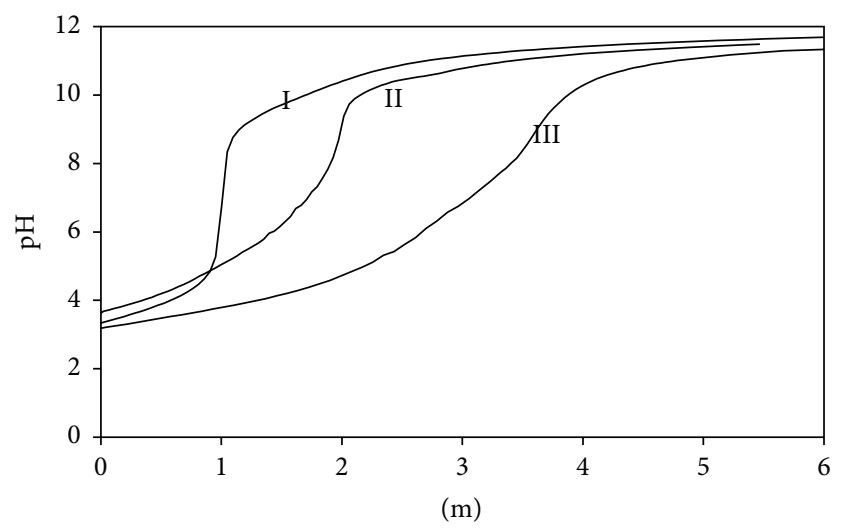

Figure 3: Potentiometric titration curves of binary complexes $(I=$ $0.1 \mathrm{~mol} \cdot \mathrm{L}^{-1} \mathrm{KNO}_{3}$ at $25.0 \pm 0.1^{\circ} \mathrm{C}$ ). Curve I: L-aspartic acid alone, curve II: $\mathrm{Ni}(\mathrm{II}): \mathrm{L}$-aspartic acid $(1: 1)$, and curve III: $\mathrm{Ni}(\mathrm{II})$ :L-aspartic acid $(1: 2)$

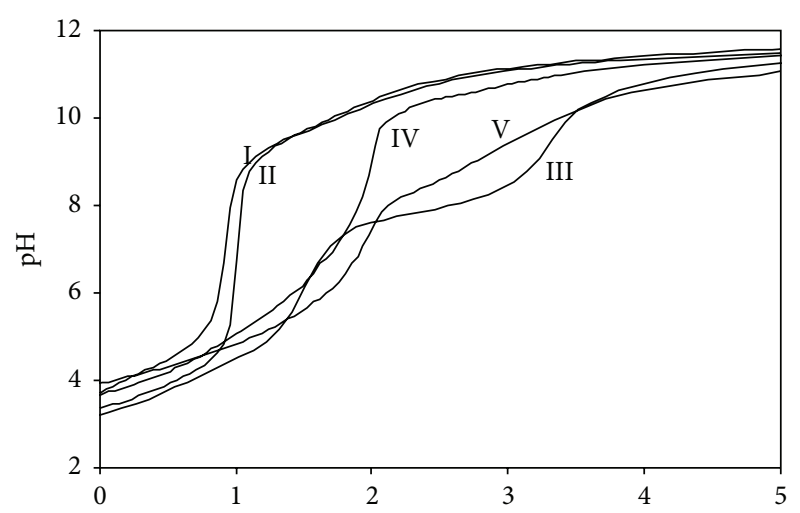

(m)

FIgURE 4: Potentiometric titration curves of binary $(1: 1)$ and ternary $(1: 1: 1)$ complexes $\left(I=0.1 \mathrm{~mol} \cdot \mathrm{L}^{-1} \mathrm{KNO}_{3}\right.$ at $\left.25.0 \pm 0.1^{\circ} \mathrm{C}\right)$. Curve I: adenine alone, curve II: L-aspartic acid alone, curve III: $\mathrm{Ni}(\mathrm{II})$ :adenine (1:1), curve IV: $\mathrm{Ni}(\mathrm{II})$ :L-aspartic acid, and curve $\mathrm{V}$ : $\mathrm{Ni}(\mathrm{II})$ :adenine:L-aspartic acid $(1: 1: 1)$.

For A (Ade),

$$
\begin{array}{cl}
\mathrm{Ni}+\mathrm{A} \rightleftharpoons \mathrm{NiA} & \beta_{1}=\beta^{\mathrm{Ni}}{ }_{\mathrm{NiA}}=\frac{[\mathrm{NiA}]}{[\mathrm{Ni}][\mathrm{A}]} \\
\mathrm{Ni}+2 \mathrm{~A} \rightleftharpoons \mathrm{NiA}_{2} & \beta_{2}=\beta^{\mathrm{Ni}}{ }_{\mathrm{NiA}_{2}}=\frac{[\mathrm{NiA}]^{2}}{[\mathrm{Ni}][\mathrm{A}]^{2}}
\end{array}
$$

(charges are omitted for the intention of clarity).

3.3. Nickel(II) Amino Acids Equilibria. Potentiometric titrations of each amino acid selected for this study were performed alone, and also in the presence of $\mathrm{Ni}(\mathrm{II})$ ion in aqueous solution in $(1: 1)$ to $(1: 3)$ stoichiometry, at $0.1 \mathrm{~mol} \cdot \mathrm{L}^{-1}$ $\mathrm{KNO}_{3}$ ionic medium, $25.0^{\circ} \mathrm{C}$, in nitrogen atmosphere. Instead of giving potentiometric titration curves for all $\mathrm{Ni}(\mathrm{II})$ :L-amino acid reactions, only $\mathrm{Ni}(\mathrm{II})$ :L-aspartic acid curves were given for simplicity (Figure 3 ). In Figures $2-4, \mathrm{~m}$ in $x$-axis represents mmole base/mmole metal or mmole 
base/mmole ligand. In order to calculate the stability constants of $\mathrm{Ni}$ (II) ion with L-amino acids used in this study, protonation constants given in Table 1 were used [23]. The stability constants of binary coordination complexes of $\mathrm{Ni}$ (II) with L-amino acids determined in this study were given in Table 2. Literature values on the stability constants of binary complexes of $\mathrm{Ni}(\mathrm{II})$ : $\mathrm{L}$-amino acids were also listed in Table 2 for comparison [36-41]. It can be seen that $\mathrm{Ni}(\mathrm{II})$ ion forms coordination complexes at $1: 1$ and $1: 2$ mole ratios with L-Asp and L-Leu, respectively. It is also clear that $\mathrm{Ni}$ (II) ion forms $1: 1,1: 2$, and $1: 3$ coordination compounds with L-Glu, L-Asn, L-Phe, and L-Trp (Table 2) [36-41].

The following equilibrium reactions and equations ((3)(5)) are given for binary complex systems which are thought that $\mathrm{Ni}(\mathrm{II})$ metal ion and each of the amino acids (B) form in (1:1), (1:2), and/or (1:3) stoichiometry:

$$
\begin{gathered}
\mathrm{Ni}+\mathrm{B} \rightleftharpoons \mathrm{NiB} \quad \beta_{1}=\beta_{\mathrm{NiB}}^{\mathrm{Ni}}=\frac{[\mathrm{NiB}]}{[\mathrm{Ni}][\mathrm{B}]} \\
\mathrm{Ni}+2 \mathrm{~B} \rightleftharpoons \mathrm{NiB}_{2} \quad \beta_{2}=\beta^{\mathrm{Ni}}{ }_{\mathrm{NiB}_{2}}=\frac{\left[\mathrm{NiB}_{2}\right]}{[\mathrm{Ni}][\mathrm{B}]^{2}} \\
\mathrm{Ni}+3 \mathrm{~B} \rightleftharpoons \mathrm{NiB}_{3} \quad \beta_{3}=\beta^{\mathrm{Ni}}{ }_{\mathrm{NiB}_{3}}=\frac{\left[\mathrm{NiB}_{3}\right]}{[\mathrm{Ni}][\mathrm{B}]^{3}}
\end{gathered}
$$

(charges are omitted for the intention of clarity).

3.4. Ternary Complexes of Ni(II) Ion. The stability constants of the ternary complexes of $\mathrm{Ni}$ (II) ions that form between $\mathrm{Ni}(\mathrm{II})$ :Ade:L-amino acids at 1:1:1 mole ratio were calculated from the potentiometric titration results. As in the binary complexes, instead of giving the graphical results for all of the ternary complexes, potentiometric titration curves for the ternary complex of $\mathrm{Ni}(\mathrm{II})$ :Ade:L-asp were given as an example for simplicity (Figure 4 ). The stability constants calculated according to (6) by the BEST computer program are also provided in Table 3:

$$
\mathrm{Ni}+\mathrm{A}+\mathrm{B} \rightleftharpoons \mathrm{NiAB} \quad \beta_{\mathrm{NiAB}}=\beta_{\mathrm{NiAB}}^{\mathrm{Ni}}=\frac{[\mathrm{NiAB}]}{[\mathrm{Ni}][\mathrm{A}][\mathrm{B}]}
$$

(A: adenine, B: amino acid).

3.5. Distribution Diagrams. Distribution diagrams of the all $\mathrm{Ni}$ (II) ternary systems were drawn by the SPE computer program [23]. Stability constants of binary and ternary complexes given in Tables 2 and 3 were used to see the changes of distributions of all types in mixed (ternary) systems as a function of the $\mathrm{pH}$ (Figures 5-10). As we see in potentiometric titration curves, the main feature of each of the distribution diagrams shown in Figures 5-10 is that NiAB ternary complexes form in $\mathrm{pH}=2.0-10.0$ range.

$\mathrm{Ni}(\mathrm{II})$ :L-Asp binary complex begins to form at $\mathrm{pH}=3$. It reaches maximum level $(15 \%)$ at $\mathrm{pH}=4.1$, and $\mathrm{Ni}(\mathrm{II}): \mathrm{L}-$ Asp complex disappears completely at $\mathrm{pH}=7$ in this aqueous solution (shown as $\mathrm{NiB}$ in Figure 5). Ni(II):Ade:L-Asp ternary complex begins to form at $\mathrm{pH}=3$. It reaches its maximum level (95\%) at $\mathrm{pH}=6$ (shown as NiAB in Figure 5).

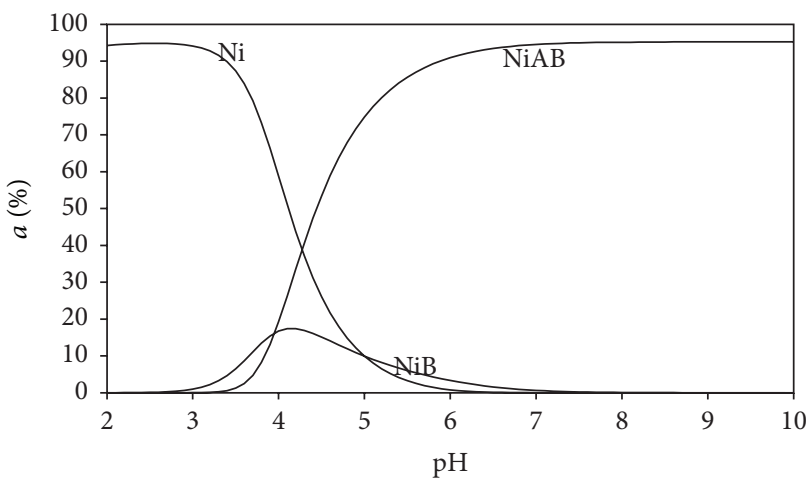

FIGURE 5: Distribution diagram of the species in the $(1: 1: 1)$ $\mathrm{Ni}(\mathrm{II})$ :adenine(A):L-aspartic acid(B) ternary system.

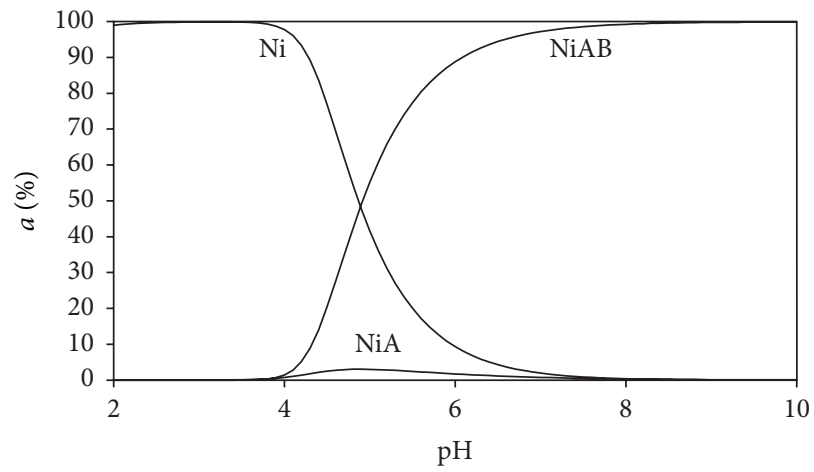

FIGURE 6: Distribution diagram of the species in the $(1: 1: 1)$ $\mathrm{Ni}(\mathrm{II})$ :adenine(A):L-glutamic acid(B) ternary system.

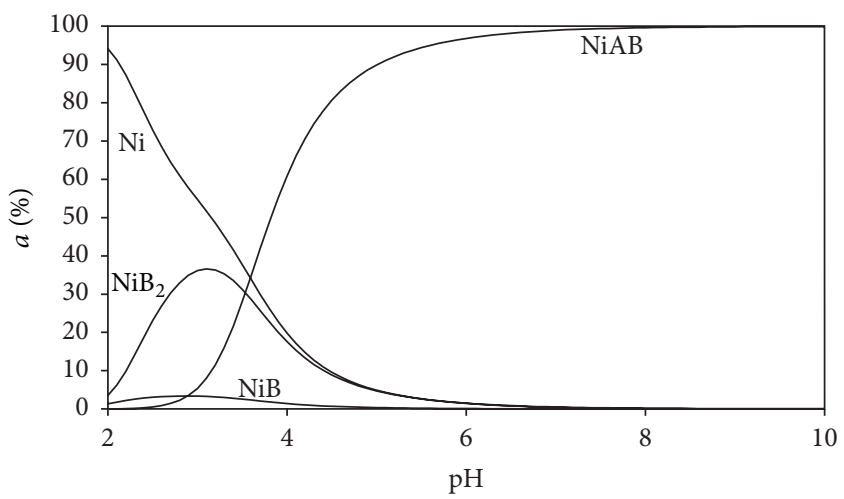

FIgURE 7: Distribution diagram of the species in the $(1: 1: 1)$ $\mathrm{Ni}(\mathrm{II})$ :adenine(A):L-asparagine(B) ternary system.

$\mathrm{Ni}(\mathrm{II})$ :Ade:L-Asp ternary complex remains stable as dominant complex in this aqueous solution between $\mathrm{pH} 6$ and $\mathrm{pH}$ 10.

$\mathrm{Ni}(\mathrm{II})$ :Ade binary complex forms at very low levels at $\mathrm{pH}$ $=4-8$ (Figure 6). At the same pH levels, Ni(II):Ade:L-Glu ternary complexes begin to form. The level of this complex reaches its maximum level (100\%) at $\mathrm{pH}=7$ (shown as $\mathrm{NiAB}$ in Figure 6).

$\mathrm{Ni}(\mathrm{II})$ :Ade:L-Asn ternary complex formation reactions were also investigated in aqueous solution. As it can be seen 
TABLE 3: The stability constants and parameters of ternary (mixed NiAB) complexes at $25.0 \pm 0.1^{\circ} \mathrm{C}, I=0.1 \mathrm{~mol} \cdot \mathrm{L}^{-1} \mathrm{KNO}_{3} . \% \mathrm{RS}$ is the percentage relative stabilization value, as explained in (12).

\begin{tabular}{|c|c|c|c|c|c|c|}
\hline & $\log _{10} \beta_{\mathrm{NiAB}}$ & $\log _{10} K_{\mathrm{NiAB}}^{\mathrm{NiA}}$ & $\log _{10} K_{\mathrm{NiAB}}^{\mathrm{NiB}}$ & $\Delta \log _{10} K$ & $\log _{10} X$ & \% R.S \\
\hline Ni(II):Ade(A):L-Asp(B) & $17.01 \pm 0.06$ & 10.35 & 8.87 & 2.21 & 0.96 & 27.14 \\
\hline Ni(II):Ade(A):L-Glu(B) & $15.57 \pm 0.06$ & 8.91 & 10.23 & 3.574 & 0.93 & 66.85 \\
\hline Ni(II):Ade(A):L-Asn(B) & $18.80 \pm 0.03$ & 12.14 & 10.78 & 4.12 & 0.85 & 51.37 \\
\hline Ni(II):Ade(A):L-Leu(B) & $16.01 \pm 0.05$ & 9.35 & 10.48 & 3.82 & 0.90 & 69.07 \\
\hline Ni(II):Ade(A):L-Phe(B) & $15.43 \pm 0.04$ & 8.77 & 6.52 & -0.14 & 0.93 & -1.57 \\
\hline Ni(II):Ade(A):L-Tryp(B) & $16.06 \pm 0.02$ & 9.40 & 10.61 & 3.95 & 1.01 & 72.48 \\
\hline
\end{tabular}

Uncertainties are expressed as \pm one standard deviation.

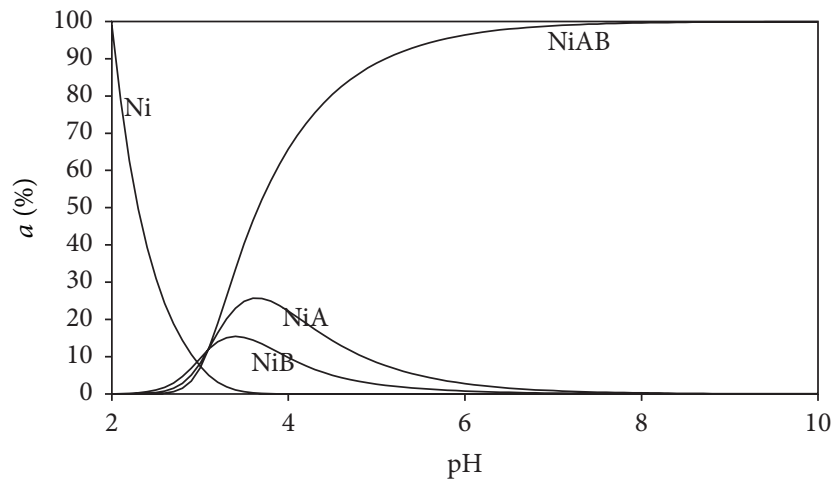

FIGURE 8: Distribution diagram of the species in the $(1: 1: 1)$ $\mathrm{Ni}(\mathrm{II})$ :adenine(A):L-leucine(B) ternary system.

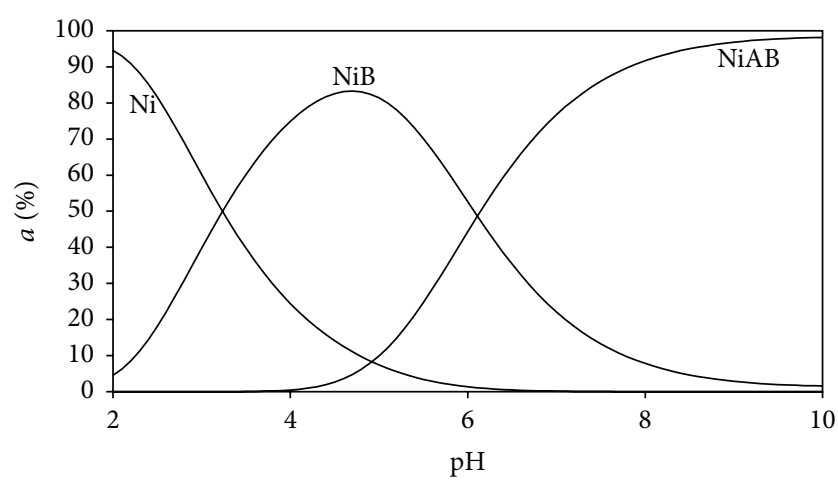

FIGURE 9: Distribution diagram of the species in the $(1: 1: 1)$ $\mathrm{Ni}(\mathrm{II})$ :adenine(A):L-Phenylalanine(B) ternary system.

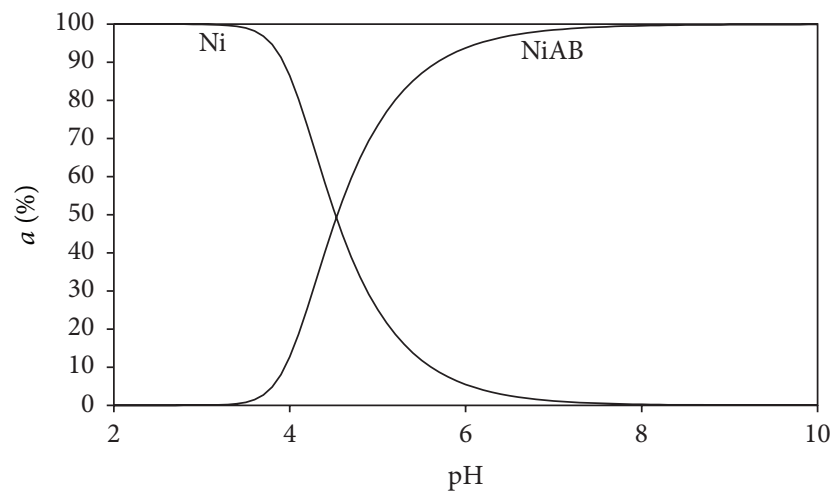

FIGURE 10: Distribution diagram of the species in the $(1: 1: 1)$ $\mathrm{Ni}(\mathrm{II})$ :adenine(A):tryptophan(B) ternary system. in Figure 7, Ni(II):L-Asn binary complexes $1: 1$ and $1: 2$ form at $\mathrm{pH} 2-6$. In addition, it may be seen that $\mathrm{Ni}(\mathrm{II})$ :Ade:L-Asn complex begins to form at $\mathrm{pH}=2$, and it reaches its maximum level (99\%) at $\mathrm{pH} 6$.

The diagrams drawn for the Ni(II):Ade:L-Leu ternary system showed a different behavior from other ternary systems analyzed in this research (Figure 8). It is clearly seen that binary ( $\mathrm{Ni}(\mathrm{II})$ :Ade and $\mathrm{Ni}(\mathrm{II})$ :Leu) and ternary (Ni(II):Ade:L-Leu) complex begin to form at the same time and at the same $\mathrm{pH}$ level $(\mathrm{pH}=2.5)$. Moreover, $\mathrm{Ni}(\mathrm{II})$ :Ade:LLeu ternary complex is present as single dominant coordination species at $\mathrm{pH}=6-10$.

$\mathrm{Ni}(\mathrm{II})$ :Ade:L-Phe ternary complex formation also shows different trends from the other complexes of $\mathrm{Ni}$ (II) (Figure 9). $\mathrm{Ni}(\mathrm{II})$ :L-Phe binary complex begins to form at $\mathrm{pH}=2$, and it reaches its maximum level $(82 \%)$ at $\mathrm{pH}=5$. $\mathrm{Ni}(\mathrm{II})$ :L-Phe binary complex begins to dissociate gradually at $\mathrm{pH}=5$, and it completely disappears at $\mathrm{pH}=10$. In this $\mathrm{Ni}(\mathrm{II})$, Ade, L-Phe mixture, $\mathrm{Ni}(\mathrm{II})$ :Ade:L-Phe type ternary complex formation begins at $\mathrm{pH}=4$ and it reaches its maximum level at $\mathrm{pH}=$ 8.5 .

Unexpectedly, in $\mathrm{Ni}(\mathrm{II})$, Ade, L-Trp system, binary complex of $\mathrm{Ni}(\mathrm{II})$ is not detectable, since the $\mathrm{Ni}(\mathrm{II})$ :Ade:L-Trp ternary complex dominates the reaction in this aqueous solution (Figure 10). Formation of $\mathrm{Ni}(\mathrm{II})$ :Ade:L-Trp ternary complex begins at $\mathrm{pH}=3.8$, and it reaches its maximum level at $\mathrm{pH}=7$.

$\log _{10} K_{\mathrm{NiAB}}^{\mathrm{NiA}}$ and $\log _{10} K_{\mathrm{NiAB}}^{\mathrm{NiB}}$ stability constants were compared with each other in order to decide which one of the ligands was contributing to formation of the mixed ligand complexes, and which one is acting as the primary or secondary ligand. For this purpose, the following equations were used:

$$
\begin{aligned}
\log _{10} \beta_{\mathrm{NiAB}} & =\log _{10} \beta^{\mathrm{Ni}}{ }_{\mathrm{NiAB}} \\
& =\log _{10} K^{\mathrm{Ni}}{ }_{\mathrm{NiA}}+\log _{10} K^{\mathrm{NiA}}{ }_{\mathrm{NiAB}}, \\
\log _{10} K^{\mathrm{NiA}}{ }_{\mathrm{NiAB}} & =\log _{10} \beta^{\mathrm{Ni}}{ }_{\mathrm{NiAB}}-\log _{10} K^{\mathrm{Ni}}{ }_{\mathrm{NiA}}, \\
\log _{10} \beta_{\mathrm{NiAB}} & =\log _{10} \beta_{\mathrm{NiAB}}^{\mathrm{Ni}} \\
& =\log _{10} K_{\mathrm{NiB}}^{\mathrm{Ni}}+\log _{10} K^{\mathrm{CBu}}{ }_{\mathrm{NiAB}}, \\
\log _{10} K^{\mathrm{NiB}} & =\log _{10} \beta_{\mathrm{NiAB}}^{\mathrm{Ni}}{ }_{\mathrm{NiAB}}-\log _{10} K^{\mathrm{Ni}}{ }_{\mathrm{NiB}} .
\end{aligned}
$$


$\log _{10} K^{\mathrm{NiA}}{ }_{\mathrm{NiAB}}$ and $\log _{10} K^{\mathrm{NiB}}{ }_{\mathrm{NiAB}}$ constants were calculated for each mixed ligand system as shown in Table 3. It can be seen that adenine acts as the primary ligand particularly in the $\mathrm{Ni}(\mathrm{II})$ :Ade:L-Glu, Ni(II):Ade:L-Leu, and Ni(II):Ade:LTrp systems and amino acids act as the primary ligand in Ni(II):Ade:L-Asp, Ni(II):Ade:L-Asn, and Ni(II):Ade:L-Phe systems.

It is quite difficult to decide the stability of the mixed ligand complexes just by taking the stability constant as the basis. Therefore, stability of mixed ligand complexes should be evaluated together with the stability of binary complexes [25]. For this purpose, the differences $\left(\Delta \log _{10} K\right)$ between the stabilities of the $\mathrm{Ni}(\mathrm{II}): \mathrm{A}: \mathrm{B}$ and $\mathrm{Ni}(\mathrm{II})$ :A were compared. $\Delta \log _{10} K$ is the value that characterizes the coordination tendency of a second ligand to $\mathrm{Ni}$ (II):A complexes associated with $\mathrm{Ni}(\mathrm{II})$. The equilibrium reaction and equation represented by (8) were calculated by the equation shown in (9). Thus,

$$
\begin{aligned}
\mathrm{NiA}+\mathrm{NiB} & \rightleftharpoons \mathrm{NiAB}+\mathrm{Ni} \\
\Delta \log _{10} K & =\log _{10} K_{\mathrm{NiAB}}^{\mathrm{NiA}}-\left(\log _{10} K_{\mathrm{NiB}}^{\mathrm{Ni}}\right) \\
& =\log _{10} K_{\mathrm{NiAB}}^{\mathrm{NiB}}-\left(\log _{10} K_{\mathrm{NiA}}^{\mathrm{Ni}}\right) .
\end{aligned}
$$

$\Delta \log _{10} K$ values for $\mathrm{Ni}(\mathrm{II}): \mathrm{A}: \mathrm{B}$ mixed ligand complexes were calculated by using (8) and (9) and the values found were given in Table 3 . When $\Delta \log _{10} K$ values were examined, it was observed that $\Delta \log _{10} K$ values obtained in all systems except the Ni(II):Ade:L-Phe system were positive. This shows that equilibrium shown in (8) (except $\mathrm{Ni}(\mathrm{II})$ :Ade:L-Phe) tends to form the ternary complex of NiAB. The results show that ternary complexes are more stable than the binary complexes analyzed in this research. However, it was also seen that $\mathrm{Ni}(\mathrm{II})$ :Ade:L-Phe ternary complex is less stable than the binary system (Ni(II):Ade or $\mathrm{Ni}(\mathrm{II})$ :L-Phe).

The second way of characterizing the formation tendency of the $\mathrm{Ni}(\mathrm{II})$ :mixed ligand complexes is $\log _{10} X$ (nonproportional dissociation constant) values [42]. This constant equilibrium expression is calculated by equilibrium equations:

$$
\begin{aligned}
& \mathrm{NiA}_{2}+\mathrm{NiB}_{2} \rightleftharpoons 2 \mathrm{NiAB} \quad X=\frac{[\mathrm{NiAB}]^{2}}{\left[\mathrm{NiA}_{2}\right] \cdot\left[\mathrm{NiB}_{2}\right]} \\
& \log _{10} X=2 \times \log _{10} \beta^{\mathrm{Ni}} \mathrm{NiAB} \\
&-\left(\log _{10} \beta^{\mathrm{Ni}}{ }_{\mathrm{NiA}_{2}}+\log _{10} \beta^{\mathrm{Ni}}{ }_{\mathrm{NiB}_{2}}\right) .
\end{aligned}
$$

When the $\log _{10} X$ 's values given in Table 3 are examined, it can be seen that, in each of the mixed ligand complexes, the $\log _{10} X$ value is bigger than the statistical value of $0.6(X=$ 4 ). This shows that the formation of mixed ligand complexes is more prevalent than binary complexes. When the $\mathrm{Ni}(\mathrm{II})$ :Ade:L-Asp $\left(\log _{10} X=0.96\right), \mathrm{Ni}(\mathrm{II})$ :Ade:L-Glu $\left(\log _{10} X\right.$ $=0.93), \mathrm{Ni}(\mathrm{II}):$ Ade:L-Asn $\left(\log _{10} X=0.85\right), \mathrm{Ni}(\mathrm{II}):$ Ade:LLeu ( $\left.\log _{10} X=0.90\right), \mathrm{Ni}(\mathrm{II})$ :Ade:L-Phe $\left(\log _{10} X=0.93\right)$, and $\mathrm{Ni}(\mathrm{II})$ :Ade:L-Tryp $\left(\log _{10} X=1.01\right)$ values are examined, it can be seen that ternary complexes, especially for $\mathrm{Ni}(\mathrm{II})$ :Ade:LTrp system, form at high percentages in all the distribution diagrams (Figure 10).
Another parameter, which is percent relative stabilization (\% RS) for quantifying the stability of a ternary complex, may be defined as [43]:

$$
\% \text { R.S }=\left[\frac{\left(\log _{10} K^{\mathrm{NiA}}{ }_{\mathrm{NiAB}}-\log _{10} K_{\mathrm{NiB}}^{\mathrm{Ni}}\right)}{\log _{10} K^{\mathrm{Ni}}{ }_{\mathrm{NiB}}}\right] \times 100
$$

The values obtained agree with the $\Delta \log _{10} K$ values as shown in Table 3.

When all the distribution diagrams are examined, it can be observed that both binary Ni:L-Phe and ternary Ni:Ade:LPhe complexes were dominant only in the Ni:Ade:L-Phe system (Figure 9). This can also be confirmed by the negative values of $\Delta \log _{10} K$ and \% RS of this system.

\section{Conclusions}

The results of this research indicate that $\mathrm{Ni}$ (II) ions can form binary and ternary complexes with adenine and L-amino acids at various combinations when these compounds are present as mixed ligand systems in an aqueous solution:

(a) Our studies suggest that adenine might be coordinated to $\mathrm{Ni}(\mathrm{II})$ ion $(72 \mathrm{pm})$ through the (N7) and the (N10) while above-mentioned amino acids might be coordinated through the amino nitrogen and carbonyl oxygen.

(b) The order of stability of the $\mathrm{Ni}$ (II) ion obtained in the mixed ligand complex systems examined in aqueous solution in this study is as follows: $\mathrm{Ni}(\mathrm{II})$ :Ade:L-Phe $<$ $\mathrm{Ni}(\mathrm{II})$ :Ade:L-Glu < Ni(II):Ade:L-Leu < Ni(II):Ade:L$\operatorname{Trp}<\mathrm{Ni}(\mathrm{II})$ :Ade:L-Asp < Ni(II):Ade:L-Asn. Regarding the $\Delta \log _{10} K$ value computed for the mixed ligand complex systems, $\mathrm{Ni}(\mathrm{II})$ :Ade:L-Asn $\left(\Delta \log _{10} K=4.12\right)$ had the highest values of stability. This, in turn, is in line with the stated order of stability.

(c) The fact that the negative $\log _{10} K$ and $\%$ RS values were obtained from the mixed ligand complex systems $\mathrm{Ni}(\mathrm{II})$ :Ade:L-Phe $\left(\log _{10} K=-0.14, \%\right.$ R.S $\left.=-1.57\right)$ shows that the stability of binary complex systems is more dominant than that of the mixed ligand complex systems. When we examine Figure 9, we can see that $\mathrm{NiB}(\mathrm{Ni}: \mathrm{L}-\mathrm{Phe})$ binary coordination compound is dominant in $\mathrm{pH}=2.0-10$ range. However, $\mathrm{Ni}$ (II):Ade:L-Phe ternary coordination compound is formed after $\mathrm{pH}=4.0$, and it is the only dominant type after $\mathrm{pH}=8.0$.

(d) When we examine Table 3 , we see that the highest $\log _{10} X=1.01$ and \% $\mathrm{RS}=72.48$ values belong to the $\mathrm{Ni}(\mathrm{II})$ :Ade:L-Trp ternary system. These values confirm the presence of $\mathrm{Ni}(\mathrm{II})$ :Ade:L-Trp as the only dominant type in Figure 10 in the $\mathrm{pH}=3.8-10.0$ range.

\section{Conflict of Interests}

The author declares that there is no conflict of interests regarding the publication of this paper. 


\section{Acknowledgments}

This research is supported by a research grant from The Scientific and Technological Research Council of Turkey (TUBITAK, Project no. 113Z600).

\section{References}

[1] R. Crichton, Biological Inorganic Chemistry: A New Introduction to Molecular Structure and Function, Elsevier Science \& Technology, 2nd edition, 2012.

[2] S. W. Ragsdale, "Nickel-based enzyme systems," Journal of Biological Chemistry, vol. 284, no. 28, pp. 18571-18575, 2009.

[3] S. W. Ragsdale, "Nickel and the carbon cycle," Journal of Inorganic Biochemistry, vol. 101, no. 11-12, pp. 1657-1666, 2007.

[4] D. P. Barondeau, C. J. Kassmann, C. K. Bruns, J. A. Tainer, and E. D. Getzoff, "Nickel superoxide dismutase structure and mechanism," Biochemistry, vol. 43, no. 25, pp. 8038-8047, 2004.

[5] T. Biver, "Stabilisation of non-canonical structures of nucleic acids by metal ions and small molecules," Coordination Chemistry Reviews, vol. 257, no. 19-20, pp. 2765-2783, 2013.

[6] K. Usdin, "NGG-triplet repeats form similar intrastrand structures: implications for the triplet expansion diseases," Nucleic Acids Research, vol. 26, no. 17, pp. 4078-4085, 1998.

[7] H. Budworth and C. T. McMurray, "A brief history of triplet repeat diseases," Methods in Molecular Biology, vol. 1010, pp. 3$17,2013$.

[8] A. Jayamani, N. Sengottuvelan, S. K. Kang, and Y.-I. Kim, "Studies on nucleic acid/protein interaction, molecular docking and antimicrobial properties of mononuclear nickel(II) complexes of piperazine based Schiff base," Inorganic Chemistry Communications, vol. 48, pp. 147-152, 2014.

[9] G. Barone, A. Terenzi, A. Lauria et al., "DNA-binding of nickel(II), copper(II) and zinc(II) complexes: structure-affinity relationships," Coordination Chemistry Reviews, vol. 257, no. 1920, pp. 2848-2862, 2013.

[10] J. J. Soldevila-Barreda and P. J. Sadler, "Approaches to the design of catalytic metallodrugs," Current Opinion in Chemical Biology, vol. 25, pp. 172-183, 2015.

[11] A. Gebler, T. Burgdorf, A. L. De Lacey et al., "Impact of alterations near the [NiFe] active site on the function of the $\mathrm{H}_{2}$ sensor from Ralstonia eutropha," The FEBS Journal, vol. 274, no. 1 , pp. 74-85, 2007.

[12] M. E. Krause, A. M. Glass, T. A. Jackson, and J. S. Laurence, "A novel tripeptide model of nickel superoxide dismutase," Inorganic Chemistry, vol. 49, no. 2, pp. 362-364, 2010.

[13] H. Sigel, Metal Ions in Biological Systems, vol. 2, Marcel Dekker Inc, New York, NY, USA, 1973.

[14] L. A. Finney and T. V. O’Halloran, “Transition metal speciation in the cell: insights from the chemistry of metal ion receptors," Science, vol. 300, no. 5621, pp. 931-936, 2003.

[15] G. Gran, "Determination of the equivalence point in potentiometric titrations. Part II," Analyst, vol. 77, no. 920, pp. 661-671, 1952.

[16] H. Rossotti, Chemical Applications of Potentiometry, Van Mostrand, London, UK, 1968.

[17] G. Schwarzanbach and H. Flaschka, Complexometric Titrations, Methuen, New York, NY, USA, 1969.

[18] G. Gran, "Determination of the equivalent point in potentiometric titrations," Acta Chemica Scandinavica, vol. 4, pp. 559$577,1950$.
[19] E. P. Serjant, Potentiometry and Potentiometric Titrations, John Wiley \& Sons, New York, NY, USA, 1984.

[20] D. D. Perrin and W. L. F. Amerago, Purification of Laboratory Chemicals, Pergamon Press, Oxford, UK, 1st edition, 1966.

[21] N. Türkel, "Stability of metal chelates of some hydroxamic acid ligands," Journal of Chemical \& Engineering Data, vol. 56, no. 5, pp. 2337-2342, 2011.

[22] R. A. Chalmers, Chemistry of Complex Equilibria, Van Nostrand Reinhold Company, London, UK, 1970.

[23] A. E. Martell and R. J. Motekaitis, Determination and Use of Stability Constants, VCH Publishers, New York, NY, USA, 1989.

[24] H. D. Demir, M. Pekin, A. K. Cücü, E. Dölen, and H. Y. Aboul-Enein, "Potentiometric studies of mixed complexes of Cobalt(II) and Copper(II) with L-asparagine and adenine," Toxicological and Environmental Chemistry, vol. 71, no. 3-4, pp. 357-367, 1999.

[25] N. Türkel, "Equilibrium study of the mixed complexes of Copper(II) with adenine and amino acids in aqueous solution," Journal of Solution Chemistry, vol. 44, no. 6, pp. 1267-1280, 2015.

[26] S. Zimmer and R. Biltonen, "The thermodynamics of proton dissociation of adenine," Journal of Solution Chemistry, vol. 1, no. 4, pp. 291-298, 1972.

[27] W. Sang-Aroon and V. Ruangpornvisuti, "Determination of aqueous acid-dissociation constants of aspartic acid using PCM/DFT method," International Journal of Quantum Chemistry, vol. 108, no. 6, pp. 1181-1188, 2008.

[28] J. L. de Miranda and J. Felcman, "Study on guanidino-carboxylate interactions in copper(II) ternary complexes of guanidinoacetic acid with glutamic and aspartic acids," Polyhedron, vol. 22, no. 2, pp. 225-233, 2003.

[29] S. A. A. Sajadi, "Metal ion-binding properties of L-glutamic acid and L-aspartic acid, a comparative investigation," Natural Science, vol. 2, no. 2, pp. 85-90, 2010.

[30] I. Sovago, T. Kiss, and A. Gergely, "Critical survey of stability constants of complexes of aliphatic amino acids," Pure and Applied Chemistry, vol. 65, no. 5, pp. 1029-1080, 1993.

[31] K. P. Anderson, W. O. Greenhalgh, and R. M. Izatt, "Formation constants and enthalpy and entropy values for the association of $\mathrm{H}+$ and $\mathrm{Cu} 2+$ with glycinate and phenylalanate ions in aqueous solution at 10, 25, and $40^{\circ}$," Inorganic Chemistry, vol. 5, no. 12, pp. 2106-2110, 1966.

[32] S. A. A. Sajadi, "Complex bilding behavior of L-tryptophan and related amino acids, a comparative investigation," American Journal of Chemistry, vol. 1, no. 2, pp. 60-64, 2011.

[33] Y. Z. Hamada, T. Burkey, E. Waddell, M. Aitha, and N. Phambu, "Reactions of $\mathrm{Zn}^{+2}, \mathrm{Cd}^{+2}$ and $\mathrm{Hg}^{+2}$ with free adenine," Journal of Applied Solution Chemistry and Modeling, vol. 2, pp. 77-84, 2013.

[34] R. A. Ammar, E. M. Al-Mutiri, and M. A. Abdalla, "The determination of the stability constants of mixed ligand complexes of adenine and amino acids with $\mathrm{Ni}(\mathrm{II})$ by potentiometric titration method," Fluid Phase Equilibria, vol. 301, no. 1, pp. 51-55, 2011.

[35] H. D. Demir, The examination of the nickel(II), cobalt(II) and copper(II) mixed complexes formed with L-asparagine and adenine, and determination of their stability constants [Ph.D. thesis], Faculty of Pharmacy, Marmara University, İstanbul, Turkey, 1995.

[36] I. Gergely, I. Nagypal, and E. Farkas, "Application of the general computational method for the determination of the equilibrium constants of the Ni(II)-aspartic acid-glycine system," Acta Chimica Academiae Scientiarum Hungaricae, vol. 82, pp. 43-55, 1974. 
[37] R. N. Patel, H. C. Pandey, and K. B. Pandeya, "Mixed ligand formation complex formation of nickel(II, copper(II) and $\mathrm{Zn}$ (II) with some amino acids and imidazoles," Indian Journal of Chemistry A, vol. 38, no. 8, pp. 850-853, 1999.

[38] N. M. Shuaib, H. M. Marafie, O. Al-Fulaij, and M. S. El-Ezaby, "Complexes of vitamin $\mathrm{B}_{6}$. 23. Interaction of some tertiary ligating amino acids with the binary complexes of $\mathrm{Ni}(\mathrm{II})$ or $\mathrm{Cu}(\mathrm{II})$ and pyridoxamine," Journal of Chemical and Engineering Data, vol. 44, no. 6, pp. 1348-1354, 1999.

[39] H. N. Aliyu and J. Na'aliya, "Potentiometric studies on essential metal (II) amino acid complexes," International Research Journal of Pharmacy and Pharmacology, vol. 2, no. 2, pp. 76-80, 2012.

[40] R. P. Phase, A. G. Shankarwar, S. G. Shankarwar, and T. K. Chondhekar, "Determination of the stability constants of mixed ligand complexes of bio-molecules and amino acids with $\mathrm{Ni}(\mathrm{II})$ by potentiometric titration method," Der Pharmacia Sinica, vol. 4, no. 3, pp. 54-58, 2013.

[41] D. R. Williams, "Thermodynamic considerations in coordination. Part VII. Solubility of the histidine $-\mathrm{H}^{+}$system and stability constants, free energies, enthalpies, and entropies of protonation of histidine and tryptophan and of formation of their manganese(II), iron(II), cobalt(II), nickel(II), copper(II), and zinc(II) complexes," Journal of the Chemical Society A: Inorganic, Physical, and Theoretical Chemistry, pp. 1550-1555, 1970.

[42] R. DeWitt and J. I. Watters, "Spectrophotometric investigation of a mixed complex of copper(II) ion with oxalate ion and ethylenediamine," Journal of the American Chemical Society, vol. 76, no. 14, pp. 3810-3814, 1954.

[43] M. M. Khalil, A.-E. Radalla, F. Qasem, and R. Khaled, "Equilibrium studies of ternary systems containing some selected transition metal ions, triazoles and aromatic carboxylic acids," Korean Journal of Chemical Engineering, vol. 31, no. 1, pp. 109119, 2014. 

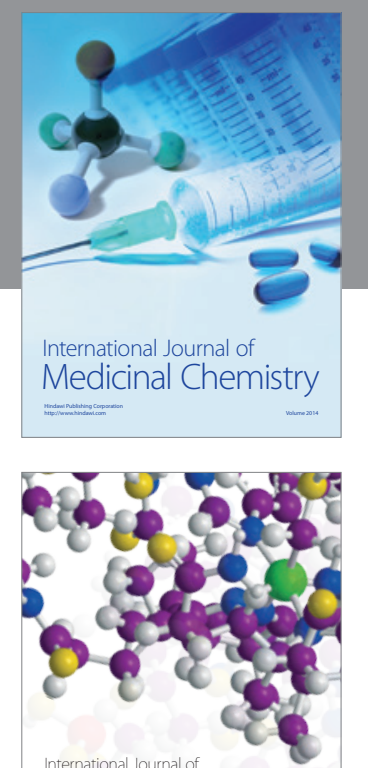

\section{Carbohydrate} Chemistry

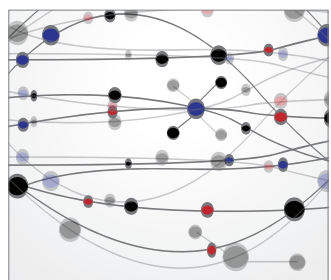

The Scientific World Journal
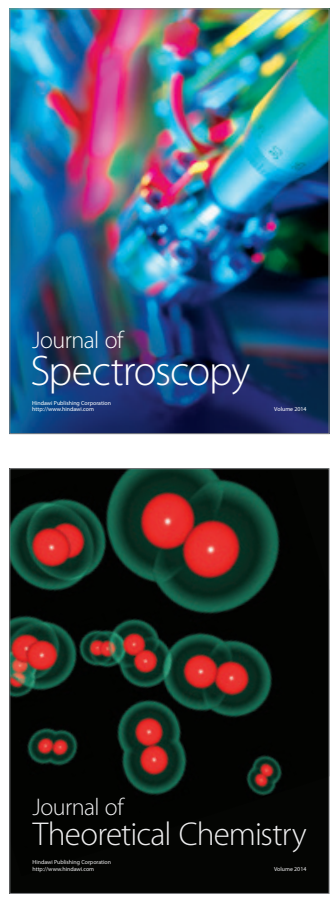
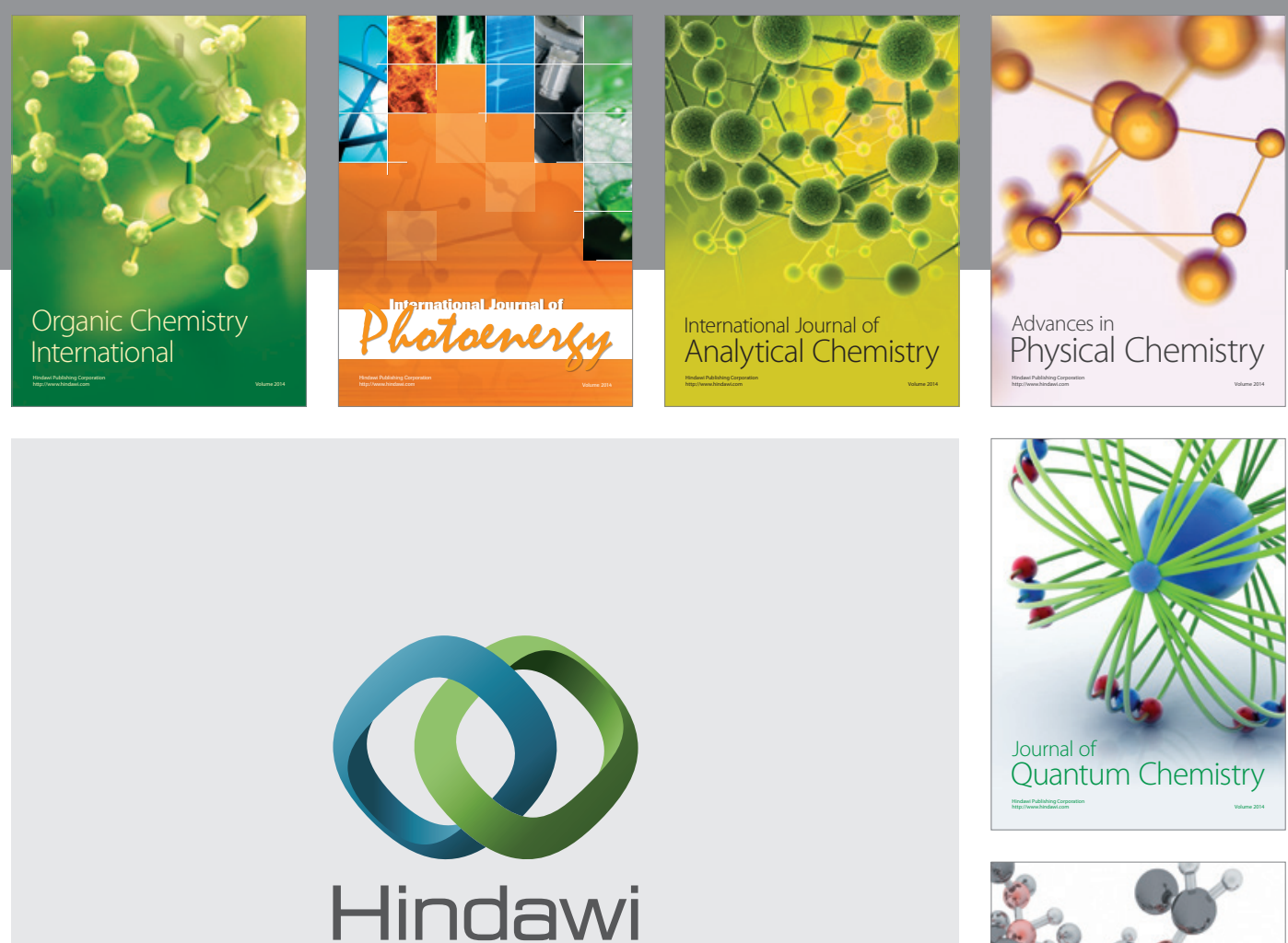

Submit your manuscripts at

http://www.hindawi.com

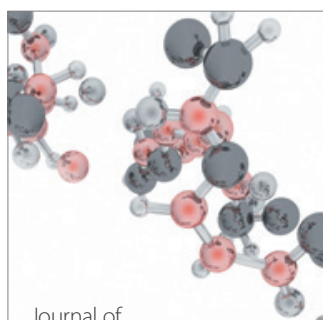

Analytical Methods

in Chemistry

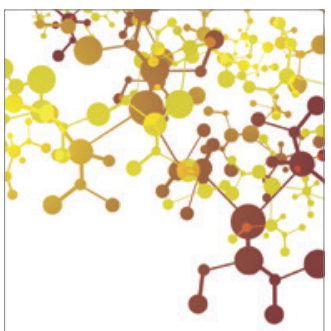

Journal of

Applied Chemistry

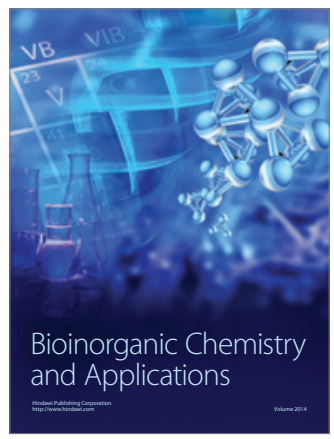

Inorganic Chemistry
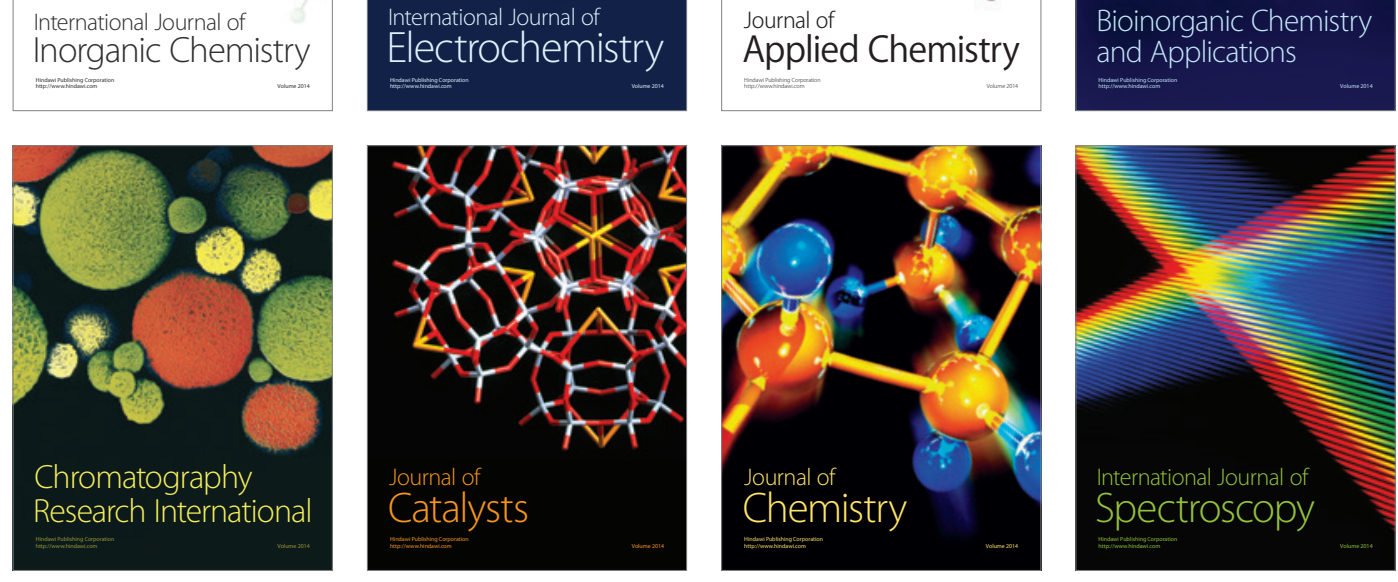